\title{
Penerapan Algoritma $K$-Nearest Neighbor pada Game Pesawat untuk Pembelajaran Matematika Dasar
}

\author{
YOULLIA INDRAWATI N, ASEP NANA HERMANA, MUHAMMAD KHARISMA \\ Program Studi Informatika, Institut Teknologi Nasional Bandung \\ Email : youllia@itenas.ac.id
}

Received 2 Oktober 2019 | Revised 15 November 2019 | Accepted 30 November 2019

\begin{abstract}
ABSTRAK
Pada tahun 2010, menurut hasil penelitian Computer Technology Reaserch (CTR), menyatakan bahwa manusia memiliki daya ingat sekitar 20\% dari apa yang dilihat dan memiliki daya ingat sekitar 30\% dari apa yang didengar. Sementara itu manusia memiliki daya ingat sekitar 50\% dari apa yang dilihat dan didengar dalam waktu yang bersamaan. Persentasi daya ingat manusia yang terbesar adalah 80\%, jika ditampilkan sesuatu yang dilihat, didengar dan sesuatu yang dipraktekkan secara bersamaan. Untuk mencapai persentasi ingatan manusia hingga 80\%, dibutuhkan suatu metode yang membutuhkan penggunaan indera penglihatan, pendengaran dan gerak tubuh secara bersamaan salah satunya adalah pembelajaran yang interaktif seperti game educative. Untuk membuat berhitung lebih menyenangkan dan bisa mengingat sebesar lebih dari 50\%, maka dirancanglah sebuah game yang bernama "Tembak Matematika" yang memiliki tampilan berupa gambar-gambar dan angka hitungan matematika serta audio. Game Tembak Matematika bisa digunakan sebagai media belajar berhitung dan mengingat untuk anak usia sekolah dasar (SD).
\end{abstract}

Kata Kunci : Berhitung, K-Nearest Neighbor ,Game, Media Pembelajaran

\begin{abstract}
In 2010, according to research results from Computer Technology Research (CTR), it was stated that humans have a memory capacity of around $20 \%$ of what is seen, and a memory capacity of about $30 \%$ of what is heard. Meanwhile, humans have a memory of about $50 \%$ of what is seen and heard at the same time. The highest percentage of human memory is $80 \%$, if displayed something that is seen, heard and something that is practiced simultaneously. To achieve a percentage of human memory up to $80 \%$, we need a method that requires the use of the senses of sight and hearing and gestures simultaneously one of which is interactive learning such as educative games. To make math more fun and be able to remember for more than 50\%, then designed a game called "Shoot Mathematics" which has a display of pictures and numbers on math and audio. Game Shoot Math can be used as a medium of learning to count and remember to children of primary school age (SD).
\end{abstract}

Keywords: Numeracy, K-Nearest Neighbor, Game, Media Education

MIND - 132 


\section{PENDAHULUAN}

Pada tahun 2010, menurut hasil penelitian Computer Technology Reaserch (CTR), menyatakan bahwa manusia memiliki daya ingat sekitar $20 \%$ dari apa yang dilihat dan memiliki daya ingat sekitar 30\% dari apa yang didengar. Sementara itu manusia memiliki daya ingat sekitar $50 \%$ dari apa yang dilihat dan didengar dalam waktu yang bersamaan. Persentasi daya ingat manusia yang terbesar adalah $80 \%$, jika ditampilkan sesuatu yang dilihat, didengar dan sesuatu yang dipraktekkan secara bersamaan. Untuk mencapai persentasi ingatan manusia hingga $80 \%$, dibutuhkan suatu metode yang membutuhkan penggunaan indera penglihatan, pendengaran dan gerak tubuh secara bersamaan salah satunya adalah pembelajaan yang interaktif seperti game educative (Musfiroh, 2008).

Untuk membuat berhitung lebih menyenangkan dan bisa mengingat sebesar lebih dari $50 \%$, maka dirancanglah sebuah game yang bernama "Tembak Matematika" yang memiliki tampilan berupa gambar-gambar dan angka hitungan matematika serta audio. Game Tembak Matematika bisa digunakan sebagai media belajar berhitung dan mengingat untuk anak usia sekolah dasar (SD) (Mastoni, 2009).

Dalam mengoperasikan game Tembak Matematika dibutuhkan algoritma K-Nearest Neighbor untuk mengetahui jarak euclidean antara pesawat jet dan alien sebagai target. Jika algoritma $K$-Nearest Neighbortidak diterapkan, maka pesawat jet tidak akan bisa mendeteksi alien yang didekatinya.

\subsection{Rumusan Masalah}

Dari latar belakang masalah penelitian yang telah disampaikan adalah bagaimana menerapkan algoritma $K$-Nearest Neighbor untuk menghasilkan game berhitung antar muka yang sesuai untuk siswa sekolah dasar kelas 4.

\subsection{Tujuan}

Tujuan Penelitian yaitu mengimplementasikan algoritma $K$-Nearest Neighbor pada game tembak untuk mata pelajaran Matematika bagi siswa Sekolah Dasar kelas 4.

\subsection{Batasan Masalah}

Pada game Tembak Matematika ini perlu didefinisikan sejauh mana pembuatan game ini dapat dikerjakan. Beberapa batasan tersebut yakni :

a. Algoritma K-Nearest Neighborhanya digunakan untuk mencari posisi alien terdekat dengan pesawat jet.

b. Game pesawat ini terdiri dari 3 buah tingkat kesulitan, yakni easy, normal, dan hard. Masing-masing tingkat kesulitan memiliki 10 level. Semakin sulit tingkatnya, semakin sulit soal yang diberikan.

1) Untuk mode easy: soal terdiri dari penjumlahan dan pengurangan.

2) Untuk mode normal: soal mode easy ditambahkan perkalian dan pembagian.

3) Untuk mode hard: soal mode normal ditambahkan akar dan pangkat.

c. Jawaban untuk setiap soal pada game ini hanya bilangan bulat.

d. Bilangan dari soal yang tersedia 0 sampai 9.

e. Multimedia Development Life Cycle diimplementasikan sampai tahap testing.

f. Target user yaitu anak usia sekolah dasar. 


\subsection{Metodologi Penelitian}

Pada pembuatan game yang berjudul "Implementasi Algoritma K-Nearest Neighbor pada game pesawat untuk pembelajaran matematika dasar" akan menggunakan metodologi penelitian Multimedia Development Life Cycle. Metodologi ini memiliki enam tahap, yaitu concept, design, material collecting, assembly, testing, dan distribution. Keenam tahapan tersebut tidak harus berurutan, tetapi tahap-tahap tersebut dapat saling bertukar posisi. Meskipun begitu, tahap concept memang harus pertama kali yang dilakukan. Tahap pengembangannya dapat ditunjukkan seperti pada Gambar 1 .

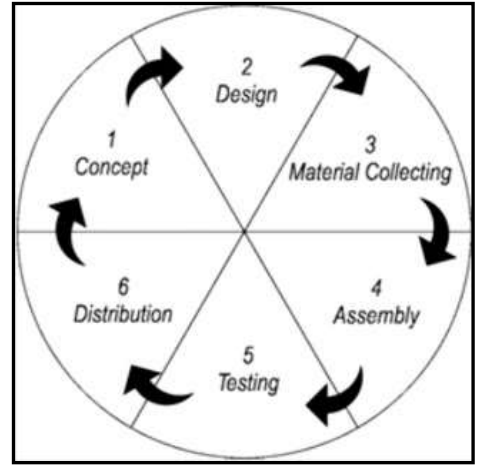

Gambar 1. Tahapan Multimedia Development Life Cycle.

\section{LANDASAN TEORI}

\subsection{Algoritma K-Nearst Neighbor}

Algoritma $K$ - nearest neighbor (KNN) adalah suatu metode untuk melakukan klasifikasi terhadap objek yang diuji berdasarkan data pembelajaran yang jaraknya paling dekat dengan objek tersebut. Algoritma $K$ - nearest neighbor (KNN) termasuk algoritma supervised learning, hasil dari query instance yang baru (objek uji) akan diklasifikasikan dalam bentuk kelas berdasarkan mayoritas dari kategori pada KNN. Kelas hasil klasifikasi adalah kelas yang paling banyak muncul (Arifin, Arieshanti, \& Arifin, 2013).

Bentuk algoritma metode $K$-Nearest Neighbor (KNN) adalah sangat sederhana. Algoritma tersebut bekerja berdasarkan jarak terpendek dari query instance ke data latih (training sample) untuk menentukan nilai KNN-nya. Data latih diproyeksikan ke suatu ruang berdimensi banyak, tiap-tiap dimensi merepresentasikan fitur dari data. Ruang ini dibagi menjadi bagianbagian berdasarkan klasifikasi data latih. Contoh sebuah titik pada ruang ini ditandai dengan nama kelas $\mathrm{C}$, karena kelas $\mathrm{C}$ merupakan klasifikasi yang paling banyak muncul pada $\mathrm{K}$ buah tetangga terdekat dari titik tersebut. Dekat atau jauhnya jarak antara objek satu dengan objek tetangga dapat dihitung berdasarkan Euclidean Distance.

Euclidean Distance merupakan rumus yang digunakan untuk menghitung jarak kesesuaian atau kedekatan. Euclidean distance berfungsi menguji ukuran yang dapat digunakan sebagai interpretasi jarak kedekatan antara dua buah obyek yang ditentukan. Perhitungan Algoritma $K$-Nearest Neighbor untuk kasus pembuatan game pesawat menggunakan algoritma $K$-Nearest Neighbor yaitu dengan mentukan titik koordinat $\mathrm{x}$ dan titik koordinat y serta menggunakan Persamaan (1) sebagai teorema Pitagoras.

$$
D=\sqrt{\left(x_{2}-x_{1}\right)^{2}+\left(y_{2}-y_{1}\right)^{2}}
$$


Teorema pitagoras berfungsi untuk mengetahui jarak antara dua buah titik, yang dinamakan jarak Euclidean.

\subsection{Education Game}

Perkembangan teknologi video game yang semakin pesat dan video game merupaka media yang efektif dan interaktif sehingga banyak dikembangkan oleh perindustrian. Hal tersebut menjadikan teknologi video game banyak diaplikasikan untuk pendidikan (edukasi) yang berbasis game. Dengan adanya keberadaan teknologi video game tersebut, banyak dikalangan pendidik untuk memberikan materi pembelajaran dengan menggunakan komponen rancangan game dan menerapkan game pada kurikulum dengan penggunaan industri berbasis game. Education game yang dibuat harus memiliki rancangan antarmuka yang interaktif dan mudah penggunaannya serta memiliki unsur menyenangkan dalam penggunaan aplikasinya (Hurd \& Jenuings, 2009).

\subsubsection{Pengertian Education Game}

Game edukasi merupakan game yang dirancang secara khusus untuk melatih pengguna dalam suatu proses pembelajaran, pengembangan konsep dan pemahaman serta membimbing mereka dalam melatih kemampuan mereka, serta memotivasi mereka untuk menggunakan dan memainkan game edukasi (Hurd \& Jenuings, 2009).

\section{METODE PENELITIAN}

Pada tahap ini akan dibahas konsep dan desain dari game yang dikembangkan sesuai dengan metodologi penelitian yang digunakan yaitu multimedia development life cycle.

\subsection{Konsep}

Pada tahap ini di paparkan konsep dari game yang dikembangkan. Berikut adalah paparan kosep game yang dikembangkan:

a. Tema

Tema yang diangkat untuk game ini adalah tantangan. Tantangan lebih di titik beratkan kepada proses berhitung.

b. Judul

Judul yang dipilih adalah Tembak Matematika. Karena user menembak alien yang mempunyai soal matematika yang mengacu terhadap jawaban pada box jawaban.

c. Tokoh/karakter

Dalam game ini terdapat dua tokoh, diantaranya :

(1) Pesawat jet

Pesawat jet mempunyai watak superhero dan bersifat protagonis, siap untuk membasmi alien-alien dengan cara menghitung jawaban yang benar lalu tembak untuk membasmi alien.

(2) Pesawat Alien

Alien mempunyai sifat antagonis siap untuk menghindari pesawat tempur yang coba untuk membasmi alien.

d. Media masukan

Media masukan yang digunakan dalam game ini adalah keyboard.

\subsection{Desain}

Tahap ini memaparkan rancangan game yang di kembangkan dan rancangan penerapan algoritma $K$-Nearest Neighbor. alur cerita direpresentasikan melalui storyboard dan storyline, sedangkan k-nearest dijelaskan melalui flowchart. 


\subsubsection{Storyline}

Storyline merupakan sebuah tulisan yang digunakan untuk mengembangkan ide cerita dalam pembuatan game. Di dalam storyline terdapat beberapa point yang menjadi gambaran secara garis besar sebuah scene tertentu. Dalam game tembak matematik yang menggunakan algoritma $K$-Nearest Neighbor, storyline yang dibuat antara lain sebagai berikut.

\section{Menu Awal}

Pada menu awal terdiri dari Play, About dan Exit.

\section{Menu Utama}

Pada menu Utama terdapat tingkan kesulitan yaitu easy, norma/dan hard.

\section{Tampilan permainan}

Terdapat pesawat jet dan beberapa alien serta jawaban dan soal.

\section{Tampilan Alien Tertembak}

Salah satu alien mempunyai soal yang benar, lalu pesawat jet menembak alien tersebut dengan menekan tombol spasi.

\subsubsection{Storyboard}

Dalam game pesawat yang menggunakan algoritma K-Nearest Neighbor, storyboard yang dibuat antara lain sebagai berikut. Gambar 3 di bawah ini adalah contoh storyboard yang menggambarkan halaman Menu Utama dari aplikasi game edukasi. Pada halaman menu utama tersebut memiliki tiga buah tombol yaitu tombol Play, About, dan Exit. Judul Game pada tengah-tengah di atas tombol play.

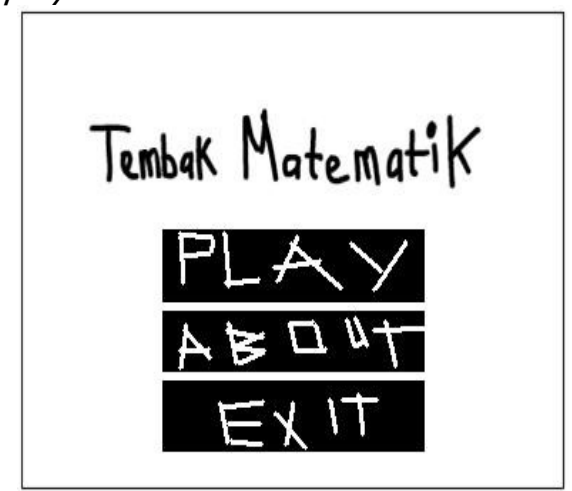

\section{Gambar 3. Storyboard Menu Utama}

\subsubsection{Flowchart K-nearest}

K-nearest diimplementasikan dalam game ini pada saat pesawat tempur menembak target. Jadi pesawat alien akan menghalangi jalan dari pesawat tempur, untuk menghindari tabrakan pesawat tempur harus menembak jatuh pesawat alien. Disetiap pesawat alien membawa 2 angka dan satu tanda operator. Pesawat alien yang bisa di tembak jatuh adalah pesawat yang apabila angkanya di hitung nilainya sama dengan jawaban yang sudah di tentukan. Karena target dari game ini adalah anak sekolah dasar maka kontrol dari game ini dibuat sederhana. Pemain tidak perlu mengarahkan tembakan ke target, pemain hanya mendekati target lalu tekan tombol spasi untuk menembak. Tembakan otomatis mengarah pada target terdekat. Untuk merealisasikan hal tersebut dapat dilakukan dengan algoritma k-nearest berikut adalah flowchart dari k-nearest: 


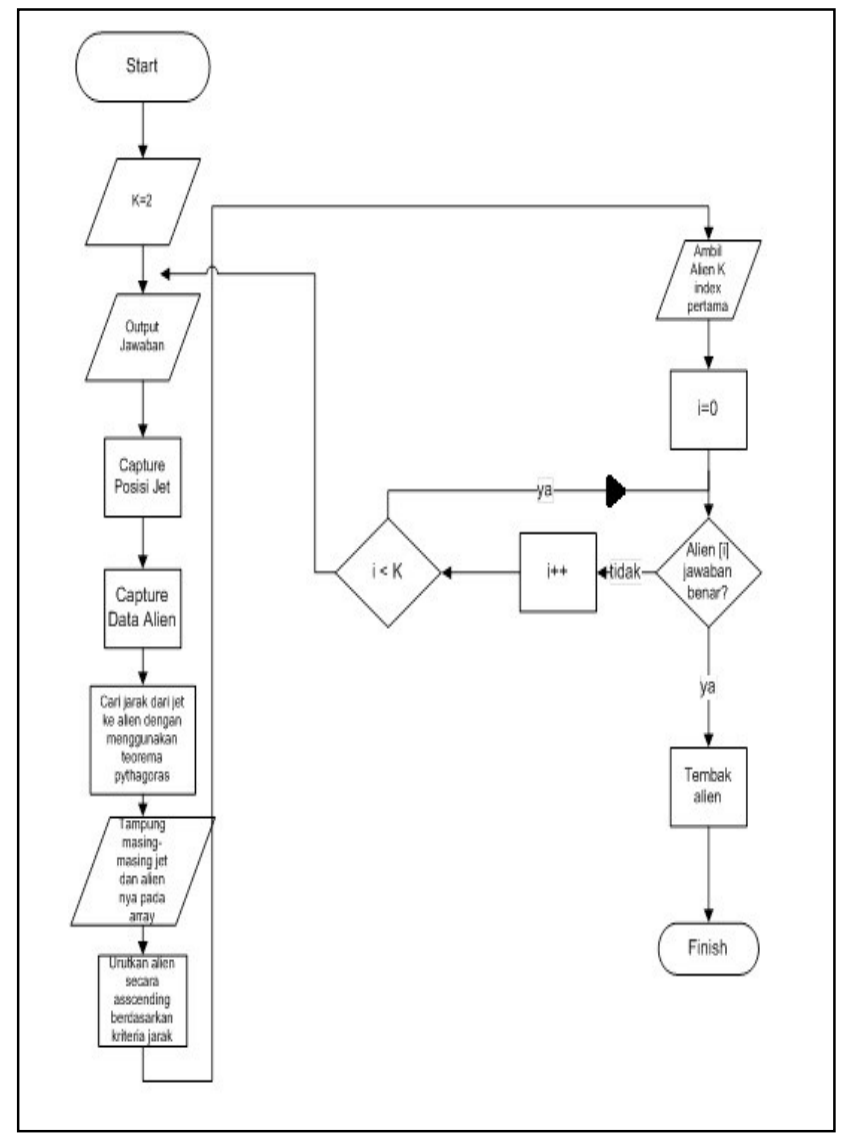

Gambar 3. FlowChart Algoritma $K$-Nearest Neighbor

\subsection{Contoh Kasus}

Contoh kasus penerapan algoritma $K$-Nearest Neighbor untuk menembak alien terdekat yang memiliki jawaban yang sesuai dengan soal :

1. Player menekan tombol tembak.

2. Maka proses $K$-Nearest Neighbor akan dimulai, yaitu:

3. Menampung jawaban dari soal, misal jika soalnya adalah $1+3=4$, maka 4 adalah nilai yang di tampung

4. Menampung data jet, dimana data yang dilihat adalah posisi jet yang di representasikan oleh $x$ dan y. misal jika jet tersebut berada di kordinat $(200,200)$ maka data di representasikan seperti Tabel 1 :

Tabel 1. Koordinat Jet

\begin{tabular}{|c|c|}
\hline Axis & Kordinat \\
\hline $\mathrm{X}$ & 200 \\
\hline $\mathrm{y}$ & 200 \\
\hline
\end{tabular}




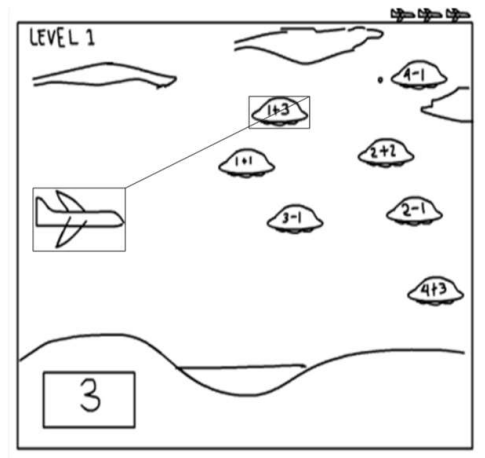

\section{Gambar 4. Perhitungan Titik Koordinat}

5. Pada Gambar 4 dijelaskan mengenai perhitungan titik koordinat yang berada di kanan atas dari gambar, menampung data masing-masing alien dimana setiap alien memiliki data: $x, y$, jawaban dan jarak, dimana data $\mathrm{x}, \mathrm{y}$ jawaban telah terisi tetapi data jarak belum terisi. Misal jika terdapat 5 alien, maka data dari 5 alien tersebut disimpan seperti yang di representasikan oleh Tabel 2.

Tabel 2. Koordinat Alien

\begin{tabular}{|c|c|c|c|c|c|}
\hline No & Alien & $\mathbf{x}$ & $\mathbf{y}$ & jawaban & Jarak \\
\hline 1 & Alien 1 & 350 & 400 & 14 & 0 \\
\hline 2 & Alien 2 & 270 & 300 & 35 & 0 \\
\hline 3 & Alien 3 & 140 & 190 & 2 & 0 \\
\hline 4 & Alien 4 & 120 & 180 & 4 & 0 \\
\hline 5 & Alien 5 & 500 & 670 & 16 & 0 \\
\hline
\end{tabular}

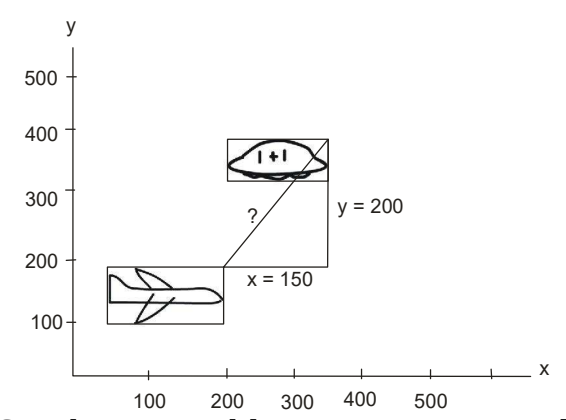

\section{Gambar 5. Perhitungan Teorema Pitagoras}

6. Pada Gambar 5 dijelaskan mengenai perhitungan pitagoras. Titik $\mathrm{x}$ dan titik y sudah diketahui, mencari panjang diagonal seperti pada Gambar 5, menggunakan teorema pitagoras dengan formula Persamaan (1) seperti berikut,

$$
D=\sqrt{\left(x_{2}-x_{1}\right)^{2}+\left(y_{2}-y_{1}\right)^{2}}
$$

Sehingga jika diterapkan pada setiap alien akan menghasilkan nilai jarak. Sebagai contoh jarak antara jet dengan alien pertama dapat dihasilkan dengan hasil akar dari (x2-x1) kuadrat + (y2-y1) kuadrat dimana:

$X 1$ : nilai $x$ dari alien 1

Y1: nilai y dari alien 1 
$\mathrm{X}$ : nilai $\mathrm{x}$ dari jet

Y2: nilai y dari jet

Sehingga jika nilai $\mathrm{x}$ dan $\mathrm{y}$ tersebut dimasukkan pada teorema pitagoras, menghasilkan:

$$
\begin{aligned}
& =\sqrt{(200-350)^{2}+(200-400)^{2}} \\
& =\sqrt{(150)^{2}+(200)^{2}} \\
& =\sqrt{22500+40000} \\
& =\sqrt{22500+40000} \\
& =\sqrt{62500} \\
& =250
\end{aligned}
$$

Maka jarak diagonal adalah 250

Data akan terbentuk pada Tabel 3 berikut ini:

Tabel 3. Koordinat Alien Setelah Dihitung

\begin{tabular}{|l|c|c|c|l|l|}
\hline Index & Alien & $\mathbf{x}$ & $\mathbf{y}$ & jawaban & \multicolumn{1}{|c|}{ Jarak } \\
\hline 1 & Alien 1 & 350 & 400 & 14 & 250 \\
\hline 2 & Alien 2 & 270 & 300 & 35 & 197.230 \\
\hline 3 & Alien 3 & 140 & 190 & 2 & 41.231 \\
\hline 4 & Alien 4 & 120 & 180 & 4 & 28.284 \\
\hline 5 & Alien 5 & 500 & 670 & 16 & 617.170 \\
\hline
\end{tabular}

7. Setelah mendapatkan semua jarak dari masing-masing alien maka urutkan alien secara ascending berdasarkan jarak, seperti Tabel 4.

Tabel 4. Koordinat Alien Setelah Dihitung Secara Ascending

\begin{tabular}{|l|c|c|c|l|c|}
\hline Index & Alien & $\mathbf{x}$ & $\mathbf{y}$ & jawaban & Jarak \\
\hline 1 & Alien 4 & 120 & 180 & 4 & 28.284 \\
\hline 2 & Alien 3 & 140 & 190 & 2 & 41.231 \\
\hline 3 & Alien 2 & 270 & 300 & 35 & 197.230 \\
\hline 4 & Alien 1 & 350 & 400 & 14 & 291.547 \\
\hline 5 & Alien 5 & 500 & 670 & 16 & 617.170 \\
\hline
\end{tabular}

8. Tentukan nilai $K$. nilai $K$ yang di pakai dalam program ini adalah $K=2$, maka ambilah alien yang berada di dalam 2 index teratas yaitu index 1 dan 2 dan dihasilkan alien 4 dan alien 3

9. Periksalah masing masing jawaban dari alien 3 dan alien 4. Apabila salah satu dari alien tersebut memiliki jawaban yang sesuai dengan soal maka tembaklah alien tersebut, apabila 2 alien tersebut memilki jawaban yang sama dengan soal maka tembaklah kedua alien tersebut, apabila kedua alien tersebut tidak memiliki jawaban yang sama dengan soal maka jet tidak akan menembak ke alien manapun maka nyawa berkurang.

\section{HASIL DAN PEMBAHASAN}

\subsection{Material Collecting}

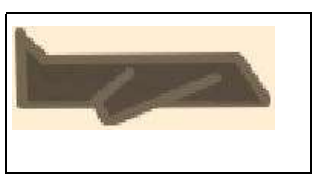

Gambar 6. Pesawat Tempur

Pada Gambar 6 adalah gambar pesawat tmpur pada game yang fungsinya sebagai pemeran utama dalam game. 


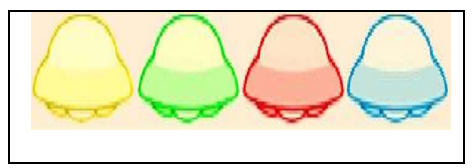

Gambar 7. Alien

Gambar 7 adalah gambar beberapa alien menurut warna nya, pada warna kuning akan muncul operator tambah (+), warna hijau akan muncul operator minus $(-)$, warna merah akan muncul operator akar (sqrt) dan pada warna biru akan muncul operator kali $(*)$.

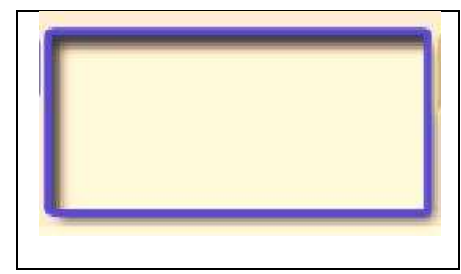

Gambar 8. Box Jawaban

Gambar 8 adalah adalah box jawaban berfungsi untuk menyimpan jawaban yang akan menjadi acuan untuk menembak alien.

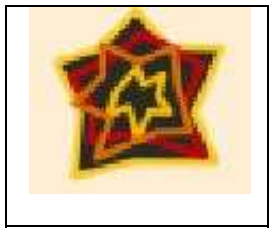

Gambar 9. Efek Tembak

Gambar 9 adalah efek dari tembakan pesawat tempur bila ada soal yang cocok dengan jawaban.

\subsection{Pengujian Sistem}

Pengujian aplikasi game edukasi ini menggunakan metode alfa dan beta, dimana metode alfa menggunakan metode black box

\subsection{1 pengujian alfa}

Pada aplikasi yang dirancang ini, dilakukan pengujian alfa untuk menjalankan algoritma $K$ Nearest Neighbor. Pengujian dilakukan untuk mengetahui apakah algoritma ini telah sesuai dengan keingina. Berikut ini akan ditampilkan tabel pengujian uang dilakukan dengan menggunakan metode pengujian Black Box serta hasil dari pengujian tersebut.

Tabel 5. Pengujian Alfa menggunakan metode Black Box

\begin{tabular}{|c|c|c|c|}
\hline \multicolumn{4}{|c|}{ Kasus dan Hasil Uji } \\
\hline Hal yang diuji & Yang diharapkan & Pengamatan & Kesimpulan \\
\hline $\begin{array}{l}\text { Menentukan nilai jawaban } \\
\text { secara random }\end{array}$ & $\begin{array}{l}\text { Jawaban tampil } \\
\text { secara random }\end{array}$ & $\begin{array}{l}\text { Jawaban tampil } \\
\text { secara random }\end{array}$ & \multirow{4}{*}{ Tercapai } \\
\hline Menampung data jet $\mathrm{x}, \mathrm{y}$ & $\begin{array}{l}\text { Data jet } \mathrm{x}, \mathrm{y} \\
\text { tertampung }\end{array}$ & $\begin{array}{l}\text { Data jet } \mathrm{x}, \mathrm{y} \\
\text { tertampung }\end{array}$ & \\
\hline Menampung data alien $\mathrm{x}, \mathrm{y}$ & $\begin{array}{l}\text { Data alien } \mathrm{x}, \mathrm{y} \\
\text { tertampung }\end{array}$ & $\begin{array}{l}\text { Data alien } \mathrm{x}, \mathrm{y} \\
\text { tertampung }\end{array}$ & \\
\hline $\begin{array}{l}\text { Mencari jarak menggunakan } \\
\text { pytagoras Antara alien dan } \\
\text { jet }\end{array}$ & $\begin{array}{l}\text { Hasil jarak Antara } \\
\text { alien dan jet }\end{array}$ & $\begin{array}{l}\text { Hasil jarak Antara } \\
\text { alien dan jet }\end{array}$ & \\
\hline
\end{tabular}




\begin{tabular}{|c|c|c|c|}
\hline \multicolumn{4}{|c|}{ Kasus dan Hasil Uji } \\
\hline Hal yang diuji & Yang diharapkan & Pengamatan & Kesimpulan \\
\hline $\begin{array}{l}\text { Ascending data jarak Antara } \\
\text { alien dan jet }\end{array}$ & $\begin{array}{l}\text { Data tersusun secara } \\
\text { ascending }\end{array}$ & $\begin{array}{l}\text { Data tersusun secara } \\
\text { ascending }\end{array}$ & \\
\hline $\begin{array}{l}\text { Tentukan dua jarak terdekat } \\
\text { Antara alien dan jet }\end{array}$ & $\begin{array}{l}\text { Terdapat dua jarak } \\
\text { terdekat Antara alien } \\
\text { dan jet }\end{array}$ & $\begin{array}{l}\text { Terdapat dua jarak } \\
\text { terdekat Antara alien } \\
\text { dan jet }\end{array}$ & \\
\hline $\begin{array}{l}\text { Mengambil salah satu } \\
\text { jawaban yang benar dari } \\
\text { dua jarak yang terdekat } \\
\text { Antara alien dan jet }\end{array}$ & $\begin{array}{l}\text { Terpilih satu jawaban } \\
\text { yang benar dari dua } \\
\text { jarak }\end{array}$ & $\begin{array}{l}\text { Terpilih satu jawaban } \\
\text { yang benar dari dua } \\
\text { jarak }\end{array}$ & \\
\hline
\end{tabular}

\subsection{2 pengujian algoritma $\boldsymbol{k}$-nearest neighbor kedalam aplikasi game}

Berikut adalah hasil dari pengujian Algoritma $K$-Nearest Neighbor dengan aplikasi , dapat dilihat dari Gambar 10.

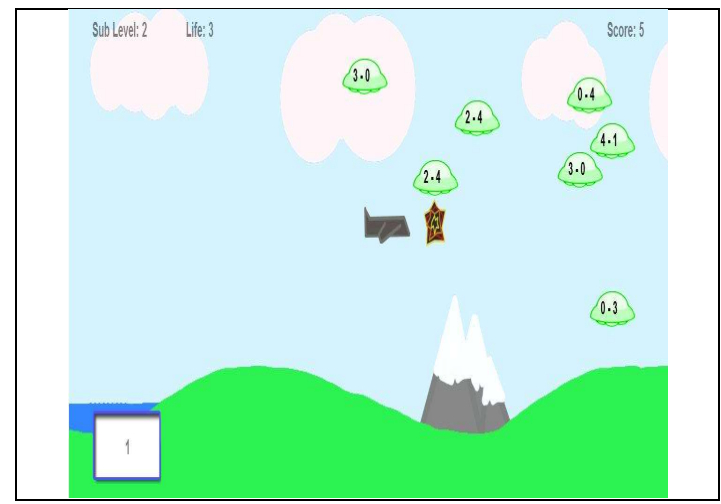

\section{Gambar 10. Hasil Algoritma $\boldsymbol{K}$-Nearest Neighbor Ke dalam Aplikasi}

Pengujian ini dapat dibuktikan, bahwa algoritma $K$-Nearest Neighbor sudah di imppletasikan kedalam aplikasi game Tembak Matematika.

\subsection{3 pengujian beta}

Pengujian ini dilakukan terhadap siswa usia sekolah dasar, pengujian beta ini berfungsi untuk mengetahui respon pemain terhadap game Tembak Matematika yang sudah terimplementasikan.

Berikut ini hasil perolehan pengujian beta:

1. Lima dari sepuluh anak menyukai game tembak matematika.

2. Lima dari sepuluh anak beranggapan game tembak matematika sulit untuk di mainkan.

\section{KESIMPULAN}

Berdasarkan dari hasil implementasi algoritma yang telah dilakukan pada game tembak matematika, dapat disimpulkan bahwa, implementasi berhasil dilakukan. Dengan adanya algoritma ini pesawat jet dapat mendeteksi dimana jawaban dari alien yang benar. Dengan berhasilnya algoritma yang diterapkan terhadap game tembak matematika ini, game Tembak Matematika ini bisa menjadi media pembelajaran alternatif untuk anak usia sekolah dasar (SD). 
Penerapan Algoritma K-Nearest Neighbor pada Game Pesawat untuk Pembelajaran Matematika Dasar

\section{DAFTAR RUJUKAN}

. (2010, September 13). Video Games Lead to Faster Decisions that are No Less

Accurate. Diambil kembali dari University of Rochester: https://rochester.edu/news/show.php?id=3679

Arifin, A. D., Arieshanti, I., \& Arifin, A. Z. (2013). Implementasi Algoritma K-Nearest Neighbor yang berdasarkan One Pass Clustering Untuk Kategori Teks. Paper and Presentation, Informatics Engineering, RSIf 518.1 Ari i, 2012. Surabaya: ITS Library. Diambil kembali dari https://docplayer.info/35029019-Implementasi-algoritma-k-nearest-neighbouryang-berdasarkan-one-pass-clustering-untuk-kategorisasi-teks.html.

Hurd, D., \& Jenuings, E. (2009). Standardized Educational Games Rating: Suggested Criteria. Karya Tulis IImiah.

Mastoni. (2009). Belajar Calistung pada Anak Usia Dini. Jurusan Matematika Fakultas Sains dan Teknologi UIN Malang.

Musfiroh, T. (2008). Cerdas Melalui Bermain. Jakarta: Grasindo.

Suyanto. (2011). Artificial Intelligence. Bandung: Informatika.

Yosep, \& Setiawan, W. (2008). Model Pembelajaran Gaya Belajar VARK dalam Mata Pelajaran

Teknologi Informasi Dan Komunikasi Berbasis Multimedia Interaktif. Universitas Pendidikan Indonesia Bandung. 